\title{
HUMAN CAPITAL OF UKRAINE: INCLUSIVE DEVELOPMENT
}

\section{Svitlana Luchyk}

Chernivtsi Institute of Trade and Economics of Kyiv National University of Trade and Economics, Department of Accounting and Taxation, Chernivtsi, Ukraine https://orcid.org/0000-0003-0757-1140

\section{Margaryta Luchyk}

Kyiv Cooperative Institute of Business and Law, Economics and Law

Faculty, Kyiv, Ukraine

https://orcid.org/0000-0002-4822-5407

\section{CMESTE}

JEL Category: 124, 125, J24

\begin{abstract}
The article is devoted to the problems of inclusive development of human capital in Ukraine. It was found out that the level of inclusiveness of economic development in Ukraine is low and has decreased in recent years. One of the reasons for this is the lack of assessment of the impact of economic reforms on the development of human capital in the country, which is a competitive advantage of Ukraine. As the result, we observe the decline in labor and social activity of the population. However, the development of a new generation of digital technologies translates into the virtual environment a significant part of labor relations and entire segments of employment, the flexibility of which is greatly increased. Digitization requires the formation of new competencies in the labor market, which entails the restructuring of the entire system of education. Ukrainian human capital is characterized by high mortality among the working population, deepening on demographic aging and depopulation, migration of the highly educated population, and increasing labor migration. It has been investigated that the population of Ukraine has a high level of education, especially a high proportion of young people with higher education. The level of inclusive education at all levels is gradually increasing. The need for significant investment in human capital to restructure all levels of education according to the requirements of inclusiveness and the formation of inclusive human capital policy, in general for economic growth and strengthening of Ukraine is substantiated.
\end{abstract}

Keywords: human capital, inclusive growth, inclusive education, inclusive society, inclusive policy

The addres of the corresponding author Svitlana Luchyk

麦=lluchiksvitlana@gmail.com

\section{INTRODUCTION}

Human capital is the main value of modern society, as well as one of the main factors of 
economic growth. It affects the development of the labor market and the economy as a whole. The digital economy is radically changing the requirements for professional and personal qualities of employees, the organization of their jobs. The challenges of the XXI century from the socio-economic environment necessitate timely changes in thinking, behavior, leadership skills, revision of the usual tools used to maintain sustainable motivation and increase productivity.

However, according to Professor K. Pissarides (Pissarides, 2017), the impact of human capital on economic development may not always be positive - much depends on what tasks the population of the country uses its skills and knowledge. Incentives that encourage people to apply their existing knowledge and skills to specific goals are important. These incentives, in turn, are largely determined by the institutional structure of the economy, but it varies greatly from country to country, making it even more difficult to measure.

The experience of the United States, many leading European and East Asian countries shows that they achieve modern success through the inclusion of human capital. At the same time, the state plays a leading role in inclusive development. It not only redistributes the results of economic and social growth but also ensures the creation of institutions of the relationship between the economy and society, between economic and social development. According to some foreign researchers (Roy, 2011), the growth of countries can be considered as inclusive only if the conditions are maintained, when simultaneously with the increase in the country's GDP is an increase in the index of human development. Under this condition, the role of the state in achieving a balance between investment policy and the development of the national innovation system increases.

According to the Inclusive Economic Development Index 2018, Ukraine ranked $49^{\text {th }}$ among 74 developing countries. According to the World Economic Forum, the inclusiveness of economic development in Ukraine has decreased by $6,8 \%$ over the past 5 years. The reasons for such negative dynamics, according to M. Novikova (Novikova 2020) is that all the reforms that have been carried out in Ukraine in recent years have begun without a proper preliminary assessment of their impact on human potential and human capital. The consequence of this is a decrease in labor and social activity of the population and a reduction in opportunities for the development of almost all sectors of the national economy. Therefore, the analysis of the process of human capital development is relevant in the context of the introduction of a new inclusive model of socioeconomic development of Ukraine and its society.

\section{INCLUSION OF HUMAN CAPITAL: THEORETICAL ASPECT}

The concepts of "inclusion", "inclusive development", "inclusive growth", "inclusive society" are widely used today. Though, Mikheev V.O. (Mikheev, 2018) under inclusion (from Latin inclusion, include, include) means the process of participation in certain actions, in politics, which allows individuals, social groups to participate equally in public life, and in decision-making. Inclusion increases the participation of all citizens in society, including people with disabilities and other low-mobility groups (the elderly, pregnant women, etc.).

The World Bank (2015) defines "inclusive growth" as high and sustainable (an important condition for poverty reduction), widespread in all sectors of the growth of the economy, which attracts a significant part of the labor force and is characterized by equal access to market and resources.

The European Commission (2010) while developing the Europe 2020 strategy emphasized that inclusive growth includes full use of labor potential through high employment and investment in skills, poverty reduction and its outcome, development of social will through education and social protection, development of regional disparities.

Thus, the key points in determining inclusive growth are broader goals than income or GDP growth; comprehensive development of human capital; reducing inequality and poverty; the importance of active participation in economic life, not only in the distribution of income; benefiting the general population, especially children, women, the elderly.

Legislation concerning Ukraine's inclusive policy is based on and may not contradict the Convention on the Rights of Persons with Disabilities (2006). 
The inclusive policy is also regulated by the Council of Europe Strategy on the Rights of People with Disabilities for 2017-2023. The Strategy for Inclusive Growth in Ukraine is presented in the form of the Draft Strategy for Sustainable Development of Ukraine until 2030, which defines "inclusiveness", "inclusive growth", and "inclusive institutions and inclusive society". Inclusive growth is defined as economic growth that creates maximum opportunities for all segments of the population for employment and participation in all spheres of life of the country, as well as ensures a fair distribution of labor results. Inclusive society - a society that does not focus on racial, gender, class, age, and geographical differences of individuals and social groups and provides equal opportunities and involvement of all members of society in creating social institutions that regulate social interaction (UNDP, 2017). The draft Strategy contains many tools and mechanisms for creating an appropriate legal framework for inclusive growth.

The document "Ukraine 2030: The Doctrine of Balanced Development" (2017) developed by Ukrainian scientists is interesting, as it presents a model of balanced development of a fundamentally new trajectory of Ukraine's economic growth until 2030. The Doctrine states that human capital is a key competitive advantage of our country. It is interpreted as "an economic category that characterizes the set of formed and developed productive abilities, personality traits and motivations of a person due to the acquired knowledge and abilities that are implemented in work. An individual is the goal for which wealth exists. The presence of educated able-bodied human capital in the country is evidenced by the $34^{\text {th }}$ ranking position of Ukraine out of 140 countries according to the World Economic Forum. On the "Quality of Mathematical and Fundamental Natural Training" $-27^{\text {th }}$ ranking position, on "Coverage of Higher Education" $-11^{\text {th }}$ ranking position, on the presence of scientists and engineers $-29^{\text {th }}$ place, while on the level of primary education - only $51^{\text {st }}$ rating position" (Ukraine 2030, 2017). But, unfortunately, in the document when developing a human-centered model of national economy development, the authors do not use the index of inclusive growth as a megaindicator. We believe that all aspects of social production and its economic growth should be considered in terms of inclusiveness. Moreover, it is inclusive changes through the transition from meeting mass are required to meet individual needs that will contribute to the development of civil society.

\section{INCLUSIVE HUMAN DEVELOPMENT IN UKRAINE}

According to the UN, which annually evaluates the Human Development Index (HDI), its indicator for Ukraine in 2019 is 0.779 , which makes it belong to the countries of a high level of human development $\left(74^{\text {th }}\right.$ place among 189 countries and territories). In the period from 1990 to 2019 , the value of Ukraine's $\mathrm{HDI}$ increased from 0.725 to 0.779 , increasing by 7.4 percent. According to the components of the index, the situation is as follows:

- the life expectancy of Ukrainians is 72.1 years.

- the mean years of schooling of the population in Ukraine are 11.4 years, and the expected time of schooling is 15.1 years.

gross national income per capita (GNI) is 13216 dollars (United Nations Development Program, 2020).

Comparison of Ukraine's HDI with a similar indicator in neighboring countries allowed us to draw the following conclusions.

The lowest human development indicators are recorded only in Moldova, which ranked $90^{\text {th }}$ in the ranking with a total index of 0.750 with a life expectancy of 71.9 years, expected years of schooling is 11.5 years, mean years of schooling11.7 years. However, GNI per capita in the country exceeds the Ukrainian figure and is 13,664 USD (Human Development Reports, 2020).

GNI in Belarus exceeds the same figure in Ukraine by $40.3 \%$ (is 18,546 USD), in the Russian Federation - by $97.9 \%$ (26,157 USD), Romania by $122 \%$ ( 29,344 USD), Hungary - by $137.1 \%$ ( 31,329 USD), Poland - by $139.3 \%$ ( 31,623 USD), Slovakia - by $143.0 \%$ (32,113 USD).

While globally Ukraine is in the category of high human development countries (HDI higher than 0.753), within the region of Europe and Central Asia it shows a lower-than-average figure (0.791) and lags behind other major countries in the region - Kazakhstan (0.825) and Russia. (0.824) (Human Development Report 2020). 
It should be noted that the procedure for determining the $\mathrm{HDI}$ in 2019 contains some amendments to consider inequalities in society, which means that the components of the index cannot be directly compared with those in previous reports. Thus, to reflect the impact of inequality on human development, the 2010 Human Development Report introduced a socioeconomic inequality-adjusted human development index (HDI), which considers inequality in all components of HDI (by "reducing" the average of each component according to the degree of inequality).

With this adjustment, Ukraine has an HDI of 0.728 , considering the "loss" of development due to inequality of $6.5 \%$. Even though Ukraine still lags both Kazakhstan (0.766) and Russia (0.740), their losses are higher by $7.2 \%$ and $10.2 \%$, respectively, which reflects the higher degree of inequality in these countries. Ukraine is also ahead of the average HDI in Europe and Central Asia (0.697), where the average loss of development due to inequality is $11.9 \%$.

Let us try to assess the above indicators. Does the improvement of Ukraine's human development indicators in the global ranking indicate an improvement in the quality of human potential in the country in the context of implementing an inclusive human capital policy?

From 1950 to 2020, the life expectancy of the planet's population has increased from 46 to 73 years and is projected to increase by another four years by 2050. Moreover, David I. Bloom (David E. Bloom, 2020) claims that by 2050 life expectancy will have to exceed 80 years in at least 91 countries, where then they will live 39 percent of the world's population.

Longer life is one of the colossal achievements of humanity, which is due to improved survival conditions throughout the life cycle, but especially in infants and children. During the years of independence, life expectancy at birth in Ukraine increased from 70.42 years (1990) to 72.01 years (2019). According to the State Statistics Service of Ukraine (2020), the highest value of the indicator was determined in Kyiv - 73.96 years, the lowest in the Zhytomyr region - 70.28 years. With the positive dynamics of life expectancy in all groups of the population in the country continues to remain high mortality. If in 1990 the mortality rate was 1220.4 per 100 thousand people, in 2019 1472.7. The situation is particularly threatening in the age groups: $35-39$ years, where mortality increased by $35.3 \%, 30-34$ - by $26.1 \%, 40-44-$ $23.3 \%$. As a result, there were changes in the age structure of the Ukrainian population. In 2019, the share of the working population aged 16-59 decreased to $54.8 \%$ against $58.8 \%$ in 1990 and $54.8 \%$ in 2010 . The age group of 60 years and older increased from $18.3 \%$ (1990) to $20.9 \%$ (2010) and again to $21.9 \%$ (2019).

Thus, demographic aging of the population is observed in Ukraine. This situation is typical for most countries. Currently, the world leader is Japan: 28 percent of its population (three times the world average) are people aged 65 and older. According to David E. Bloom (David E. Bloom 2020), by 2050, 29 countries and territories will have a larger share of the elderly population than Japan today. The study of the demographic burden per 1,000 people aged 16-59 in Ukraine revealed the following trends: from 1990 to 20082009 there was a decrease from 708 to $553-554$ people. Since 2010, the figure is gradually increasing and has reached 671 people by the end of 2019 , including 272 people under the age of 16 and 399 people over the age of 60 . In the regions of the country, the worst situation is in Chernihiv (717 people with a distribution of 247 and 470 people, respectively) and Donetsk regions (716 people with a distribution of 213 and 503 people). The best value of the load indicator in the Kharkiv region is 633 people (239 and 394 respectively).

Changing age dynamics and increasing demographic burden have a serious impact on economic growth, social stability, and geopolitics. All this affects how people save, spend and where they invest money. Ukrainian experts (The National Academy of Sciences of Ukraine, 2020) say that the aging population poses many challenges, primarily related to public finances including increasing the need for pension funds; functioning of the labor market (with an aging workforce and declining working population) in general), development of the health care system and social services aimed at the elderly, etc.

The economic burden of an aging population can be reduced through various appropriate measures. Thus, migration between countries is of some importance for population growth. In some 
countries, such as Tonga, Samoa, and Guyana, where net emigration has been felt for the past 30 years, its effects are significant. Qatar, the United Arab Emirates, and Bahrain have the highest levels of net immigration. Besides, among the world's ten demographic superpowers, the relative presence of migrants is highest in the United States (15 percent in 2019) (David E. Bloom, 2020). According to United Nations estimates by M. Petrakis (2020), due to the aging and migration of the population of Central, Eastern, and SouthEastern Europe will be reduced by 2050 by $12 \%$. The number of labors will decrease by a quarter over the same period.

The migration movement in Ukraine since 2005 has a positive balance in Ukraine (State Statistics Service of Ukraine, 2020). At the end of 2019, the migration increase amounted to 21512 people, including 18,222 interstate migrants. 8 regions of Ukraine had an increase in migration, among them the largest inflows of migrants took place in the Kyiv region 27,343 people, Kyiv - 17,175 people, and Odesa region -9075 people. In other regions, there was a reduction in migration Donetsk and Luhansk regions lost 7680 and 4940 people, respectively, Kirovograd and Vinnytsia regions 3345 and 2724 people, respectively.

Labor migration, which is an integral part of the labor market, can, on the one hand, increase the inclusiveness of a country's economic growth, while, on the other hand, contribute to its reduction. This will depend on the level of quality of the migrant workforce.

Migrants are usually people of working age. They increase the employed population of the host country, thereby compensating for its natural decline. Also, the infusion of highly skilled migrants into knowledge-intensive industries contributes to the rapid development of the latter. While the influx of low-skilled immigrants, according to many scientists (Chepel, Tukhtarova Neklyudova, 2018), contributes to attracting capital to labor-intensive medium and low-tech sectors of the economy, which can lead to its stagnation due to intensive infrastructure without modernization. In other words, capital is being replaced by labor and the country's development is being carried out at the expense of extensive sources.
Thus, the influx of qualified personnel has a positive effect on the economic growth of the recipient country. However, the donor country remains in a difficult position. The large-scale outflow of skilled labor in the medium term begins to have a negative impact on the development of certain sectors of the economy, and the long-term consequences of the outflow of skilled workers are reflected in changes in qualitative and quantitative indicators of human capital in the country. This triggers a negative multiplier effect and reduces the scientific and economic, we believe, inclusive, potential of the donor country.

A necessary condition for the inclusiveness of society is the general access of the population to education. Well-educated citizens have higher productivity, helping their countries to prosper, while differences in accumulated human capital explain much of the differences in income levels between countries and over time.

According to the ranking of countries according to the HDI (Humanitarian Portal, 2020), the average duration of education in Ukraine in 2019 was 11.4 years, and the expected duration of education 15.1 years. Compared to the leaders of the rating, the highest average duration of training was achieved in Germany - 14.2 years, Switzerland 13.4 years. The highest values of the expected duration of training are in the ranking leaders Norway (18.1 years) and Ireland (18.7 years). According to the level of education (World Bank Development Research Group, 2020), Ukraine ranks high $46^{\text {th }}$ with a score of 0.797 . Compared to neighboring countries, the highest rating is Poland (23rd position), followed by Belarus (30), Russia (33), Slovakia (35), Hungary (39). Moreover, countries such as Romania and Moldova are behind in $55^{\text {th }}$ and $79^{\text {th }}$ positions.

Inclusiveness in education means providing a situation in which every student sees that he or she is valued and respected. However, discrimination, stereotypes, rejection led to the alienation of many students. These mechanisms of alienation are essentially always the same, regardless of gender, place of residence, income, disability, ethnicity and language, migration, displacement, sexual orientation, imprisonment or freedom, religious and other beliefs, and attitudes.

Inclusive education is being developed in Ukraine. We consider the development of the draft National 
Strategy for the Development of Inclusive Education until 2030 to be a significant achievement in this direction. According to the project, a domestic inclusive educational environment and the system of educational services must meet international standards. This will guarantee students the opportunity to learn, regardless of their special educational needs, at all levels of education throughout life. At the end of 2020 , there were 18,687 inclusive classes in Ukraine (The Ministry of Education and Science of Ukraine, 2020), and 30.9 thousand children with special educational needs were enrolled. In the field of inclusive education, 17.2 thousand teacher assistants were trained to work in inclusive classrooms. Despite the quarantine restrictions caused by COVID-19, inclusive education funding of UAH 504 million was maintained, and for the first time, the budget financed the purchase of equipment for special schools and training and rehabilitation centers. For the first time, a mobile application of the IRC AS was introduced to help parents of children with special educational needs.

Regarding higher education, according to the State Statistics Service of Ukraine (State Statistics Service of Ukraine 2020) in the 2019/2020 academic year 13,988 people with special educational needs studied in higher education institutions of the country, which is less than $1 \%$ of the total number of students. It should be noted that $76.6 \%$ of them studied in universities, academies, institutes, and others - in colleges, technical schools. For comparison: in the United States in 2019, among students with a bachelor's degree, young people with special educational needs accounted for $19.4 \%$, and among graduate students $-11.9 \%$. In British universities, the share of students with special needs was $14.3 \%$. The Covid-19 pandemic has radically changed the format of the educational process. Not all participants in this process were ready to receive information in the context of distance learning. Students with disabilities need special attention during this period. Long-term online learning for students with disabilities can be a particularly difficult task, given that students' disabilities can range from mild to severe. Many of them need special tools, special tasks, and individual support to help them succeed. Teachers need to keep students with disabilities at the forefront when developing and teaching courses, creating curricula. Inclusive education involves not only the creation of appropriate educational space but also the provision of psychological and pedagogical support, the involvement of specialists with many years of experience in working with people with special needs.

It should be noted that currently all levels of education are being restructured to include inclusiveness. According to $O$. Mamedov (Mamedov, 2017), "the sphere of education is the primary local model of future changes, which later covers all spheres of society. In this aspect, inclusive training of high school graduates makes sense only if they are waiting for inclusivereorganized production. However, the inclusion of society is not limited to education. According to the scientist (Mamedov, 2017), inclusive-reorganized production entails a corresponding transformation in distribution, exchange, and consumption. At the same time, inclusive changes will cover health care, science, the social sphere, recreation, and tourism - almost all public life. This is the system in practice. "

Thus, investing in human capital development, in education, promotes inclusive growth and development, which is also influenced by the availability of medical infrastructure for the population. All members of society must be provided with the means to form the basic human capabilities that are the most important foundation of social integration.

\section{CONCLUSIONS}

Human capital is the most valuable economic resource, so its growth in the country's economy is one of the key factors of strategic growth. Carriers of human capital, who can use it effectively in their work, are key creators of added value. Moreover, it gives both a direct contribution to GDP and an indirect one, i.e., due to the growth of total factor productivity - the ability to produce more and cheaper per unit cost of labor and capital. Another thing is that the size of this contribution is determined not only by human capital itself but also by the actions of those who use it. Among the external effects of human capital should be noted the higher quality of social ties, civic activism, and culture of society.

Countries that have a higher quality of human capital and have learned better than others to form 
and use the knowledge, skills, competencies of people, their ability to further study, gain significant competitive advantages. Ukraine remains a country with a high level of human development. Its human capital is of high quality and is a competitive advantage of the country. However, it is gradually becoming a scarce economic resource. Among the reasons: high mortality of the working population, deepening demographic aging, and depopulation, migration of highly educated population, increasing labor migration.

The pandemic of coronavirus infection COVID-19 has dealt a significant blow to the human capital of our country, as well as the whole world. The disease claimed the lives of tens of thousands of Ukrainians. The closure of schools has reduced the level and loss of quality in education and exacerbated inequality. The crisis caused by the pandemic has highlighted the urgent need to invest in the development of digital skills and technologies to facilitate distance work and provide distance learning, especially for groups with special educational needs.

We believe that to preserve its most valuable economic resource, Ukraine needs to significantly increase investment in human capital, as currently, the per capita income of Ukrainians in real terms is lower than in neighboring European countries. Inclusive human capital development policy must become a systemic object. Such a policy will help to overcome the increase in labor productivity, create conditions for increasing the activity of citizens, their responsibility. The widespread use of computer technology and the Internet has revealed an interesting relationship: the higher the creativity of production, the stronger the trend towards inclusiveness.

\section{WORKS CITED}

Bloom, D. E. (2020). Population 2020. Demographics can be a powerful driver of the pace and process of economic development. Finance \& Development, March 2020, 4-9. Retrieved from https://www.imf.org/external/russian/pubs/ft/fandd/2020/03/pdf/changing-demographics-andeconomic-growth-bloom.pdf

Chepel, S. V., Tukhtarova, E. Kh., Neklyudova, N.P. (2018). Migration: A factor or a barrier to inclusive economic growth in the post-soviet states. Journal of economic theory, 15(4), 579-591. Retrieved from https://elibrary.ru/download/elibrary_36715942_88155038.pdf. doi: 10.31063/2073-6517/2018.15-4.4

Economic Growth: The Role of Human Capital. (2017). Retrieved from https://www.hse.ru/news/science/211875128.html

European Commission. (2010). Europe 2020 A strategy for smart, sustainable, and inclusive growth. Retrieved from https://ec.europa.eu/eu2020/pdf

Human Development Report 2020. (2020). The next frontier Human Development and the Anthropocene. Retrieved from http://hdr.undp.org/sites/default/files/hdr2020.pdf

Human Development Reports (2020). Latest Human Development Index Ranking. Retrieved from https://hdr.undp.org/en/content/latest-human-development-index-ranking

Humanitarian Portal. (2020). Ranking of the countries of the world according to the index of education level. Retrieved from https://gtmarket.ru/ratings/education-index.

Mamedov, O. (2017). Ekonomika inklyuzivnoy tsivilizatsii (Engl. The economy of an inclusive civilization). Terra Economicus, 17(3), 6-18. Retrieved from https://cyberleninka.ru/article/n/ekonomika-inklyuzivnoy-tsivilizatsii. (In Russian)

Mikheev, V. A. (2018). Inclusive Policy of the Human Capital Development. Vlast (The Authority), 26(1), 30-36. Retrieved from https://www.jour.fnisc.ru/index.php/vlast/article/view/5628.

Novikova M. M (2020). The influence of human capital on the inclusive growth of the national economy. Proceedings from Inclusive economic development in the face of global challenges of today. 2020: International scientific and practical Internet conference (1-28 February 2020) (pp. 66-68) 
Kharkiv: KhNUMG them. OM Beketova. Retrieved from https://science.kname.edu.ua/images/dok/konferentsii/2020konf/1-28.pdf

Petrakis M. (2020). The exodus from Eastern Europe. Finance \& Development. March 2020, 24-25. Retrieved from https://www.imf.org/external/russian/pubs/ft/fandd/2020/03/pdf/future-of-agingpopulations-and-economic-growth-in-eastern-europe-petrakis.pdf.

Roy A. (2011). Inclusive Growth through MFIs' Outreach in Assam. Asia-Pacific Business Review. 7(3), 47-62. doi: 10.1177/097324701100700305.

State Statistics Service of Ukraine. (2020). Higher education in Ukraine. Retrieved from http://www.ukrstat.gov.ua/.

State Statistics Service of Ukraine. (2020). Migration of population by region (2002-2019). Retrieved from http://www.ukrstat.gov.ua/.

State Statistics Service of Ukraine. (2020). Tables of births, deaths, and average life expectancy for 2019: a statistical collection. Retrieved from http://database.ukrcensus.gov.ua/PXWEB2007/ukr/publ_new1/2020/zb_tabl_nar_2019.pdf

Stratehiya staloho rozvytku Ukrayiny do 2030 roku (Engl. The strategy of sustainable development of Ukraine for the period up to 2030). Project-2017. Retrieved from https://www.undp.org/content/dam/ukraine/docs/SDGreports/UNDP_Strategy_v06optimized.pdf.

The Ministry of Education and Science of Ukraine. (2020). The Ministry of Education and Science presents the achievements of inclusive education in 2020. Retrieved from https://mon.gov.ua/ua/news/mon-prezentuye-dosyagnennya-inklyuzivnoyi-osviti-u-2020-roci.

The National Academy of Sciences of Ukraine. (2020). Ukraine on the demographic map of the world: can there be 52 million of us again? Retrieved from http://www.nas.gov.ua/UA/Messages/Pages/View.aspx?MessagelD=6659.

The World Bank. (2015). Ending Poverty and Sharing Prosperity. Global Monitoring Report 2014/15. Washington DC: International Bank for Reconstruction and Development. Retrieved from http://pubdocs.worldbank.org/en/637391444058280425/GMR-2014-Full-Report.pdf

Ukraine 2030: The Doctrine of Balanced Development (2017). Retrieved from http://econom.chnu.edu.ua/wp-content/uploads/2018/03/E-Book-Doctrine-2030.pdf

United Nations Development Programme. (2020). Human Development Index (HDI) Ranking From the 2020 Human Development Report (2020). Retrieved from http://hdr.undp.org/en/content/latesthuman-development-index-ranking

Received for publication:

Revision received:

Accepted for publication:
11.02.2021

24.02.2021

06.07.2021

\section{How to cite this article?}

Style - APA Sixth Edition:

Luchyk, S., \& Luchyk, M. (2021, July 15). Human capital of Ukraine: Inclusive development. (Z. Cekerevac, Ed.) MEST Journal, 9(2), 45-53. doi:10.12709/mest.09.09.02.07

Style - Chicago Sixteenth Edition:

Luchyk, Svitlana, and Margaryta Luchyk. 2021. "Human capital of Ukraine: Inclusive development." Edited by Zoran Cekerevac. MEST Journal (MESTE) 9 (2): 45-53. doi:10.12709/mest.09.09.02.07. 
Style - GOST Name Sort:

Luchyk Svitlana and Luchyk Margaryta Human capital of Ukraine: Inclusive development [Journal] // MEST Journal / ed. Cekerevac Zoran. - Belgrade - Toronto : MESTE, July 15, 2021. - 2 : Vol. 9. - pp. 45-53.

Style - Harvard Anglia:

Luchyk, S. \& Luchyk, M., 2021. Human capital of Ukraine: Inclusive development. MEST Journal, 15 July, 9(2), pp. 45-53.

Style - ISO 690 Numerical Reference:

Human capital of Ukraine: Inclusive development. Luchyk, Svitlana and Luchyk, Margaryta. [ed.] Zoran Cekerevac. 2, Belgrade - Toronto : MESTE, July 15, 2021, MEST Journal, Vol. 9, pp. 45-53. 